\title{
Escrita escolar, caminho religioso: o caderno de Albino Luciani - Papa João Paulo I
}

\author{
Ademir Valdir dos Santos ${ }^{1}$ \\ http://orcid.org/0000-0002-5958-689X
}

\section{Resumo}

0 artigo tem como objeto um caderno escolar, considerado como meio através do qual se pode conhecer o que se ensinou e como foi ensinado, registrando discursos que transmitem valores relacionados ao currículo e à ação dos sujeitos. Pertenceu a Albino Luciani, que o construiu entre 1922 e 1923, quando era aluno da quarta elementar de uma escola da atual Canale d'Agordo, municipalidade onde nasceu, localizada no norte da Itália. Os objetivos são: caracterizar as práticas educativas registradas; analisar o conteúdo da escrita questionando seu papel na transmissão de valores religiosos associados à formação da infância; e discutir os nexos entre os conteúdos do caderno e a posterior trajetória de vida. A metodologia é embasada na análise de conteúdo. As análises mostram que nas 78 páginas há redações, cartas, exercícios e ditados. Várias escritas apresentam elementos de ensino da religião que pregam atitudes cristãs e preceitos ético-morais, destacando a caridade, a compaixão, o respeito e o amor à família; alguns textos tratam da disciplina, dos castigos e de falhas como jogar pedras, mentir, ser hipócrita e blasfemar contra Deus. São evidentes as contribuições formativas da escola primária italiana, indicando um ambiente histórico e uma cultura escolar com forte presença do ensino religioso. Os resultados ratificam interpretações que vinculam aspectos culturais - que foram ensinados e aprendidos na infância - à posterior trajetória de formação que levou à escolha profissional de essência religiosa, culminando com o papado.

\section{Palavras-chave}

Caderno - Prática educativa - Ensino da religião - Papa João Paulo I.

1- Universidade Federal de Santa Catarina (UFSC), Florianópolis, SC, Brasil. Contato: ademir.santos@ufsc.br 


\section{School writing, religious path: the exercise book of Albino Luciani - Pope John Paul I}

\section{Abstract}

The subject of this a school exercise book (notebook), considered as a means through which one can know what was taught and how it was taught, registering discourses that transmit values related to the curriculum and the action of individuals. It belonged to Albino Luciani, who made it between 1922 and 1923 when he was a pupil in the fourth grade of an elementary school in the current Canale d'Agordo, a municipality where he was born, located in northern Italy. The objectives are: to characterize the educational practices written down; to analyze the content of writings by inquiring about its role in the transmission of religious values associated with the education of childhood; and discuss the connections between the contents in the exercise book and the subsequent life course. The methodology is based on Content Analysis. Analyses show that, along 78 pages, there are essays, letters, exercises and dictations. Several writings include elements of religious teaching that preach Christian attitudes and ethical-moral precepts, emphasizing charity, compassion, respect, and love of the family; some texts talk about discipline, punishments, and misdemeanors such as throwing stones, lying, being hypocritical, and blaspheming against God. The formative contributions of Italian elementary school are evident, indicating a historical environment and a school culture with a strong presence of religious teaching. The results ratify interpretations that connect cultural aspects taught and learned in childhood - to the subsequent trajectory of formation that led to a professional choice of religious essence, culminating in the papacy.

\section{Keywords}

Exercise book - Educational practice - Religious teaching - Pope John Paul I.

\section{Introdução}

Nas anotações do pároco de uma localidade setentrional italiana encravada na bela cadeia montanhosa das Dolomitas, a pequena Forno di Canale, consta que aos 17 dias do mês de outubro de 1912, nasceu uma criança que necessitava ser batizada às pressas. 0 frágil recém-nascido Albino Luciani corria perigo de vida. Em meio àquele ambiente nublado pela tristeza do incerto amanhã, o operário católico Giovanni, seu pai, assim como a dona de casa e devota mãe, Bortola Tancon, se poucas expectativas nutriam quanto ao destino do filho, não poderiam jamais imaginar que ele viria a se tornar o Papa Sorriso: João Paulo I. E que, futuramente, um similar e pesado confronto da alegria com a tristeza viria a marcar o curto hiato entre a festejada eleição do ilustre belunês 
para o papado, em 26 de agosto de 1978, e sua súbita morte em 28 de setembro, após um brevíssimo pontificado.

Pensando nos processos de formação humana, é possivel afirmar que várias foram as influências que possibilitaram o delinear de um percurso tão raro e importante em meio à cristandade. A família e a parentela, assim como as diversas instituições educativas formais por que Albino Luciani passou desde a infância, podem ser invocadas como responsáveis pelo seu contato com valores morais e com princípios doutrinários da Igreja Católica, que foram internalizados e nutriram uma trajetória de vida dedicada à religião.

Neste estudo, focalizo a escola como ambiente formativo, uma vez que as pesquisas a respeito das práticas educativas registradas nas escritas escolares põem em evidência sua contribuição na construção do patrimônio cultural da humanidade, desvelando mecanismos de produção dos saberes e sua circulação. Tomo como objeto específico o conteúdo de um caderno escolar, documento que, de acordo com Gvirtz e Larrondo (2008, p. 39), é um meio através do qual se pode conhecer o que se ensinou e como foi ensinado, compreendendo-se a escrita como geradora de efeitos e a escola como produtora de discursos que transmitem valores vinculados ao currículo e à ação dos sujeitos, compondo a cultura escolar.

Tal caderno pertenceu a Albino Luciani, que o construiu entre 1922 e 1923, enquanto aluno da quarta elementar da escola de Forno di Canale. Único documento desta natureza, integra o acervo do Museo Albino Luciani, dedicado à preservação de objetos pessoais, documentos diversos e fotografias, assim como da biblioteca particular do ex-pontífice. ${ }^{2}$ Embora posicionando o caderno como fonte principal, tenho clareza de que ele não reflete toda a atividade escolar, mas corroboro a afirmação de que:

[...] os cadernos devem ser situados como fonte histórica no contexto das práticas e pautas escolares, sociais e culturais de sua época, seu uso há de completar-se e combinar-se com outras fontes históricas. (VIÑA0, 2008, p. 27).

A metodologia tem por base a análise de conteúdo proposta por Bardin (1977), que foi aplicada às escritas do caderno elaboradas pela própria criança em resposta às prescrições do programa curricular. Quanto aos objetivos da pesquisa, são os seguintes: caracterizar a natureza das práticas educativas registradas; analisar o teor da escrita interrogando seu papel na transmissão de valores de base religiosa associados à formação da infância e discutir o estabelecimento de nexos entre os conteúdos do caderno e a posterior trajetória de vida de seu autor.

\section{O caderno como corpus para a análise de conteúdo: codificação e categorização}

0 caderno de Albino é uma pequena brochura, medindo 19,8 centímetros de altura por 15 centímetros de largura. A capa, na cor verde clara, é em papel de gramatura maior

\footnotetext{
2- Agradeço a Loris Serafini pelo acesso ao acervo do Museo Albino Luciani. 0 museu está situado em Canale d'Agordo, a antiga Forno di Canale, na província de Belluno. Em setembro de 2016, foram inauguradas as novas instalações museológicas, com a presença do secretário de Estado do Vaticano, o cardeal Parolin.
} 
que a utilizada nas folhas do miolo. A frontal tem margens decoradas por uma padronagem tipográfica em tinta preta, composta por retângulos preenchidos por arabescos figurativos estilizados que lembram plantas, flores e frutos entrelaçados, em meio a que se destaca o perfil de uma ave de asas abertas e longa plumagem na cauda. Essa espécie de moldura tem no seu centro impressa a palavra QUADERNO e, abaixo, duas linhas tracejadas que foram ocupadas com a escrita manual do nome do aluno, na primeira, seguida pela identificação da classe, na segunda. Contém 39 folhas pautadas com 19 linhas, frente e verso, que estão todas preenchidas com escrita à pena.

Considerados os aspectos metodológicos vinculados aos usos de cadernos escolares em pesquisas, afırma-se que eles são fontes complexas que possibilitam a construção de abordagens no cruzamento de pelo menos três campos historiográficos complementares: "a história da infância, a da cultura escrita e da educação”; acrescenta-se que são documentos com escritos ou desenhos elaborados pelas próprias crianças com base no incentivo do meio escolar, mesmo que diante do "caráter disciplinado, controlado e condicionado pelos adultos"; quer dizer, o caderno vem a ser um lugar da escrita que "[...] permite entrever, em ocasiões, a "personalidade" do aluno, além de incluir referências a si mesmo, a seu mundo familiar e a seu entorno social." (VIÑA0, 2008, p. 16-17).

Quanto à análise de conteúdo, é dividida em três fases distintas, "a pré-análise, a exploração do material e o tratamento dos resultados, a inferência e a interpretação" (BARDIN, 1977, p. 89). 0 caderno escolar na íntegra foi considerado como corpus de análise. Assim, tendo em mãos fotografias digitais de cada uma das páginas, por meio da leitura flutuante ${ }^{3}$, verifiquei a ocorrência daquelas que passamos a considerar as palavraschave das escritas registradas, as quais constituem os indicadores a serem utilizados para a interpretação. Essas ações correspondem à etapa de pré-análise.

De acordo com Bardin (1977, p. 95-100), a fase de exploração possibilita a codificação, processo pelo qual o pesquisador sistematiza e agrupa os dados com intuito de descrever as características do conteúdo, por meio da escolha de recortes do texto em unidades de registro, pela definição de regras de contagem e pela classificação e agregação do teor da escrita em categorias temáticas. Estabeleci três unidades de registro: ditado (dettato), tema (tema) e exercício (esercizio).

0 ditado pode ser entendido tanto como a ação do professor de expor ou comunicar palavras que devem ser anotadas precisamente pelos alunos, como o texto que é resultado da escrita do que foi dito pelo docente. A presença dos ditados é associada a práticas tradicionais de ensino, porque são centradas na atuação docente e no controle que este exerce sobre a seleção dos conteúdos escolares e a forma com que são transmitidos.

Quanto ao tema, é proposto como um argumento que serve de base para a composição de um texto por parte dos discentes. No caso do caderno analisado, é apresentado como uma pequena frase, afırmativa ou interrogativa, com base na qual o estudante deveria desenvolver sua redação. Por isso, após a apresentação do tema sempre há a palavra svolgimento, ou seja, a indicação de que o aluno a partir dali irá desenvolver uma narrativa

3- Constituída pelas várias leituras realizadas para se conhecer os textos, até que se atinja uma exaustividade considerada suficiente. 
com base no proposto. Como ato redacional, o tema solicita o gradual desenvolvimento de uma argumentação, arrolando uma série de circunstâncias coligadas entre si.

0 exercício indica a realização de escrita com finalidade didática que contribui na consolidação de uma capacidade solicitada para o aprendizado, ao mesmo tempo em que funciona como testagem para verificar se o aluno é capaz da conservação de uma prática dada como correta, fornecendo as respostas esperadas e aceitas. Pode ser ainda entendido como treinamento, guardando um caráter de repetição, aspecto que também o aproxima das práticas escolares consideradas tradicionais.

0 caderno significa um modo de nos avizinharmos da sala de aula, de nos aproximarmos da criança por meio do que produziu em suas atividades escolares:

Os trabalhos ou deveres dos alunos incluem uma ampla variedade de modalidades escritas (exames, cópias, composições, redações, ditados, resolução de problemas, análises gramaticais, cartas etc.). (VIÑAO, 2008, p. 17).

Considerando que cada unidade de registro é uma componente textual de significação, constituída por parágrafos, frases e palavras, sua atenta leitura analítica possibilitou a identificação de palavras-chave que compuseram uma primeira categorização. Essa foi obtida na conjugação de dois procedimentos: 1) classificação dos termos da escrita através das similaridades terminológicas, ou seja, agrupando enunciados selecionados pelo grau de proximidade, exprimindo significados e elaborações importantes relacionados aos objetivos deste estudo, encontrados não somente na parte visível e aparente dos textos, mas também nas entrelinhas dos enunciados; e 2) constatação por meio de contagem, após sucessivas leituras flutuantes, de que alguns termos são repetidos e revelam, em linhas gerais, a natureza da prática educativa registrada.

$\mathrm{Na}$ análise de conteúdo, as palavras-chave que equivalem às primeiras categorias são agrupadas de acordo com temas similares e dão origem às categorias iniciais. Em seguida, da reunião temática das categorias iniciais se compõem as categorias intermediárias, sendo que estas, ao serem novamente aglutinadas devido à ocorrência de temas comuns, resultam nas categorias finais. 0 que orienta o processo é a busca pela compreensão dos sentidos e significações das escritas, sejam esses repetidos ou agregando outros e novos significados.

Por fim, já na terceira fase, que abrange o tratamento dos resultados, a inferência e a interpretação, segue-se na direção de captar tanto os conteúdos explícitos como aqueles tacitamente delineados. Nessa etapa cabe a comparação entre categorias oriundas das análises, de modo a colocar em evidência aspectos de similaridade - o que pode gerar fusão de termos - ou de diferenciação.

Apresento, em seguida, a categorização resultante da análise aplicada ao teor das escritas referente a cada uma das unidades de registro obtidas na codificação e relacionadas à prática educativa: ditados, temas e exercícios. Dessa metodologia emerge a riqueza de conteúdos do caderno escolar do pequeno montesino. 


\section{Ditando valores e comportamentos}

Os ditados correspondem à palavra codificadora ou unidade de registro mais frequente no caderno analisado, somando 30 incidências. Detecto que, em sua maioria, eles são constituídos de sequências de frases ou palavras soltas, sem conexão entre si, assim como se percebe que aquilo que foi ditado pelo professor e registrado por vezes não estabelece vínculos com a realidade da criança, servindo para um treino da habilidade de ouvir e, em seguida, tentar escrever com correção ortográfica e gramatical. Mas isso não implicou que algumas das frases, mesmo que isoladas, fossem carregadas de significados e intencionalidades.

Vejamos um desses ditados, composto por orações desconexas: Vi um belo cão; Quem tem um coração é bem querido; $O$ ano tem 365 dias. ${ }^{4}$ Note-se, todavia, que o conteúdo da segunda frase indica elementos de afetividade - coração e bem querido -, contendo terminologia que pôde ser registrada no processo de categorização.

Outro ditado, datado de três de janeiro de 1923, assume um caráter mais complexo, pois além da finalidade de aprendizado linguístico, há um teor civilizatório, apresentando aspectos comportamentais que poderiam ser aprendidos, também, através da escola. Em uma livre tradução de um excerto: "Quando era pequeno eu não sabia me comportar à mesa: colocava as mãos no prato da mamãe, não usava o garfo e faca, sujava minhas mãos, rosto e roupas".

Noutros casos, o teor pode ser relativo a aspectos do programa. Um ditado serviu para fixar conteúdos que hoje atribuímos à disciplina escolar de ciências. Faz alusão a Benjamim Franklin, como inventor do para-raios, que "me livra das terriveis descargas elétricas que podem me incinerar, e não lembro de Benjamim Franklin, o inventor daquele simplíssimo instrumento de salvação". Depois fala de Pasteur: "Eu poderei curar da raiva ou hidrofobia e de outras doenças infecciosas; e mesmo assim não pronuncio com reconhecimento o nome de Pasteur". Portanto, afirmando que se deveria agradecer aos cientistas pelos seus inventos, embora isso nem sempre seja lembrado. Desde aqui a gratidão é indicada como categoria inicial.

Há um ditado com conteúdo de história, temperado de juízos. Trata de Giuseppe Mazzini, que teve uma vida dedicada à pátria e morreu em Pisa em 1872, sem ver o “sonho de redenção e de unidade”. É apresentado como um herói, autor de belas palavras para os italianos, exaltando o patriotismo e valores associados:

Amai-vos. Amai a família, os homens prontos a dividir alegrias e dores como vocês: os mortos que lhes foram caros e que seriam caros. A Pátria é o pensamento de amor que abraça, que une todos os filhos de uma nação.

A composição categorial vai sendo composta com referência aos valores como o amor à família, a solidariedade, o apreço e a união.

4- Todas as traduções são de minha responsabilidade. Todas as citações foram retiradas das seguintes fontes documentais: 1) LUCIANI, Albini. Lettera per la Giornata del Seminario. 27 de outubro de 1962 e 2) LUCIANI, Albino. QUADERNO di Luciani Albino no. 8. Classe IVa. Elementare. Forno di Canale: [s. n], 1922-23. 
Analiso um dos ditados que devia ser convertido ao plural. Além de exigir domínio da língua, está impregnado de valores, nesse caso ligados à condição de ser estudioso, o que implicaria uma mudança de vida. A adjetivação refere-se à moralidade apregoada, porque além de aludir a características e condutas da vida humana, enfatiza posturas necessárias na escola e um código de preceitos a atender.

É mesmo preciso que mudemos de vida: necessita que nos distanciemos dos colegas rebeldes, que não percamos tempo em passatempos vãos: é preciso que sigamos os conselhos do professor e de nossos pais. De agora em diante é necessário que façamos todo esforço para nos tornarmos rapazes estudiosos: é bom, por isso, que sejamos verdadeiramente disciplinados, que na escola estejamos sempre atentos e em casa façamos precisamente todos os nossos deveres.

Em vários trechos é perceptível um fundo moral, que visava a incutir valores a serem incorporados e repelir outros não desejáveis:

Existem dentre vocês estudantes que no ano passado repetiram a classe. Certos rapazes no outro ano não quiseram dar ouvidos e este ano, ao invés de frequentarem a quarta, devem repetir a terceira.

Na sequência, há um conjunto de frases que enfatiza características dos maus e dos bons rapazes, em um antagonismo do bem versus o mal. Os defeitos mais comuns: apressado, dispersivo, indiscreto, preguiçoso, curioso, presunçoso, melancólico, maledicente, descortês, invejoso e mentiroso. Já as belas qualidades: ativo, bom, ingênuo, inteligente, sensivel, desinteressado, generoso, simples, alegre, disposto, reconhecedor, compassivo, dócil.

Do ditado realizado em 27 de dezembro de 1922, extraio escritas impregnadas de mensagens formativas. Indica-se o que é bom e o que é prejudicial na conduta do estudante como no seio da família, com vários adjetivos, comparações e condicionantes. Os grifos indicam categorias iniciais que emergem da análise de conteúdo.

A água estagnada, pútrida, túrbida da imagem do aluno negligente, que desperdiça o tempo no ócio. Sem ser bom em família, sem obedecer aos pais, não se pode ser bravos estudantes. Este aluno, eu não o amo porque é mentiroso, este outro o estimo porque é leal. 0 anjo da família é a mãe. A boa ação realizada de alma revela a sua índole generosa. Como é belo no homem o amor pela virtude, o horror e o desprezo pelo vício. (Grifos do autor).

E na última página do caderno consta um ditado moralístico. Fala principalmente da mentira e de suas consequências. Expõe o conteúdo em frases de impacto: "Nunca mentir! Sejam sinceros, ó crianças.”

Ficou evidente que ao mesmo tempo em que fixavam a ortografia e a gramática, os ditados serviam à transmissão de mensagens incidentes sobre a formação infantil. Analisados os vários ditados e atentando para a terminologia empregada, foi possível compor, pela frequência e carga semântica em torno dos mesmos significados, categorias iniciais e intermediárias relacionadas à formação humana. Uma das categorias intermediárias é a 
dos valores morais: amor (ao trabalho e à família), gratidão, sinceridade (verdade, não mentir), cumprir com os deveres, generosidade e afetividade são as categorias iniciais que aglutino para essa composição. ${ }^{5}$ Destaco que esta categorização está intimamente ligada a uma ética de julgamento que os textos emanam, marcada pelo antagonismo entre o bem e o mal. Outra categoria intermediária é a escolarização, que compreende as categorias iniciais: boa educação, limpeza, ocupar o tempo, aprendizagem, escrita, leitura, ouvir os adultos, disponibilidade e alegria. ${ }^{6}$ Conformo ainda a categoria intermediária comportamento, que evidencia e agrupa princípios de conduta como responsabilidade, obediência, cuidado, disciplina, operosidade, virtuosidade e superação.

\section{Dos temas: destacando a formação infantil}

Os temas foram originados com base em propostas de conteúdos a serem tratados pela criança em uma redação própria e original. Constituem fonte riquíssima para acessar elementos do complexo universo infantil em formação, desvelando aspectos de formação pertinentes ao indivíduo, ao ambiente familiar e escolar e aos contextos sociais e culturais. 0 tema precisa ser desenvolvido, ou seja, impulsionar um svolgimento. Ou ainda dar origem a uma pequena narrativa ou conto, um racconto ou raccontino. No corpus documental analisado constam 23 temas. $^{7}$

Ressalto que o primeiro tema elaborado por Albino Luciani e registrado nesse caderno se chama "A igreja do meu lugar", datado de 12 de dezembro de 1922 e aparecendo já na primeira página. 0 menino situa a igreja na localidade em que vivia com a família: "A igreja do meu lugar está na praça de Forno". Seja imponente ou pequenina, geralmente a igreja ocupa uma posição central na organização espacial da cidade. Mas, sobretudo, vincula à questão espiritual e ao simbolismo e ritualidade do pertencimento religioso, lembrando dos vínculos com o divino e transcendental.

Em seguida, descreve as portas do edifício e denomina o arquiteto responsável. Mas detenho-me na descrição que faz de outros elementos da estrutura sacra: "Há também o batistério onde levam as crianças para batizar, e o púlpito onde vão dar a prédica”. Remete ao necessário rito de entrada e pertencimento na religião católica, à representação do acesso a uma comunidade de fé. Segue fazendo referência ao lugar para os cânticos, em que se pode inferir sobre a alegria de louvar, sempre presente como conduta de um homem que foi chamado de Papa Sorriso: "Depois existe o lugar de cantoria onde se vai cantar". Segundo Serafini (2004, p. 9), em 1977, já na condição de Patriarca de Veneza, Albino Luciani escreveu, a pedido do maestro veneziano Lino Tortani, uma narrativa sobre suas recordações de infância, em que relatou suas sensações ao ouvir o órgão daquela igreja:

\footnotetext{
5- Categorias iniciais mais frequentes na escrita. Mas há outras palavras-chave que ocorreram e que guardam correlação como aquelas mais citadas: respeito, lealdade, caridade (compaixão), união e apreço.

6- Note-se que as componentes desta categoria intermediária não estão isentas de uma carga de moralidade, sendo que as más qualidades evidenciadas por alguns sujeitos na escola são trazidas como parâmetro de comparação: pressa, dispersão, indiscrição, preguiça, presunção, melancolia, maledicência, descortesia, inveja e mentira.

7- Devido ao limite de espaço deste artigo, selecionei alguns temas para análise.
} 
Em Canale eu fui uma criança de família pobre. Mas quando, entrando na igreja, escutava o órgão tocar a plenos tubos, eu esquecia as minhas pobres vestes e tinha a impressão de que o órgão saudasse particularmente a mim e aos meus pequenos companheiros como se fôssemos príncipes. Daqui a primeira, vaga intuição, transformada depois em seguida em certeza convicta, de que a Igreja católica não é somente algo grandioso, mas que faz grandes também os pequenos e os pobres, honrando-os e enaltecendo-os. ${ }^{8}$

A narrativa atenta, voltada aos detalhes arquitetônicos e de ornamentação, mas também às práticas religiosas, indica percepção sobre o cuidado com os lugares destinados aos ritos. Acrescenta uma descrição dos altares internos: o principal dedicado a São João Batista, outro em devoção da Imaculada Conceição, o do Sagrado Coração de Jesus e o altar dos mortos. Assim, acrescenta que "Sob o altar de São João Batista está o tabernáculo esculpido pelo escultor Brustolon”. E indica a presença da sacristia, onde estão as indumentárias e paramentos sagrados. Por fim, fala dos cinco confessionários, outro ponto essencial da arquitetura de uma igreja por toda a carga de fé que representa: a possibilidade do arrependimento e do perdão.

Como estratégia de desenvolvimento de habilidades de escrita e leitura do alunado, mas principalmente como veículo para a transmissão de conteúdos formativos, cabe ainda destacar a presença das cartas, que são um formato especial dado aos temas. Localizo um desenvolvimento no qual se percebe uma série de valores e atitudes a que a criança faz menção. Ele devia ser elaborado com base na escrita de uma carta ao papai para que comprasse o livro Il cuore (0 coração), de Edmondo de Amicis. Nesse texto destaco palavras-chave relacionadas aos valores e atitudes cristãs importantes para a formação. Da leitura flutuante foi possível selecionar os seguintes termos ou frases para composição das categorias iniciais: leitura, livro, coração, fazer as lições, favor com prazer em fazer algo ao outro, generosidade, ser bom, ajudar, prometer, limpeza, irmãos menores/família, responsabilidade e acreditar. Também ficam delineadas várias racionalidades: boas atitudes e dedicação sempre serão recompensadas; o arranjo da família paternalista onde o pai é o provedor; o papel de estudante a que Albino se dedica, sendo o que lhe cabe naquele momento da vida. A organização do pensamento do menino mostra estar sendo nutrida de valores fundantes da conduta, próprios da cultura cristã, e que são reconhecidos tanto no âmbito da família como na escola.

Dentre a variedade de propostas temáticas registradas, trago uma redação em que se subentende o propósito de revigorar a importância do Natal, data cristã. Eis o proposto para ser desenvolvido: "Giulietta deseja com ansiedade que chegue finalmente o dia de Natal. Por quê?". 0 menino Albino responde com um pequeno conto. 0 teor evidencia bons hábitos e valores que farão com que a personagem seja recompensada com um vestido novo mediante boas notas na escola, de acordo com uma promessa que o seu pai havia feito já no início do primeiro bimestre (lembrando que na Itália este começa em setembro). A menina teria sido sempre empenhada nos estudos: "Todo tempo livre ela usa no estudo". Mais que isso, jamais cabula a escola: "Nunca mata aula e é sempre atenta e obediente". A

8- Grifos meus sobre o texto original de Dom Albino Luciani. 
historieta continua dizendo que Giulietta obteve belas notas e por isso o pai já comprou o vestido, que ela teria oportunidade de vestir no Natal. Vê-se delineada a lógica de que a dedicação e as boas atitudes são recompensadas. Conduzidos pela escrita de Albino, somos orientados ao terreno dos comportamentos ideais e das relações harmoniosas.

Encontro um tema sugerido cujo propósito disciplinador é evidente, mesmo sendo uma narrativa que poderia se referir a eventos imaginários: "Durante a ausência do professor nasce um desagradável incidente”.

Ontem às dez horas, enquanto estávamos fazendo a leitura, veio um homem chamar o senhor professor para negócios importantes. Os dois companheiros da $3^{\text {a }}$ fila e do $3^{\circ}$ banco começaram a discutir entre si. Mesmo sabendo que quando o Senhor Professor está ausente devemos nos comportar bem, ainda melhor, não nos fazermos ver mal educados e incivis por aquela pessoa que poderia ser uma pessoa instruída e educada, quem sabe até um professor de outra cidade, que não se conhece. Eles, ao invés, não quiseram seguir os conselhos do professor e na briga viraram o tinteiro e a tinta caiu num livro de leitura e no assoalho. 0 senhor professor os castigou severamente. Depois da aula todos os dois tiveram que ir para casa buscar água quente e lavar, e um teve que gastar dinheiro para comprar outro (livro). Esperamos que os dois companheiros se corrijam do feio vício de brigar entre si quando o senhor professor está ausente, especialmente se tiver alguma pessoa que o chamou, que então sim se mostram mal educados e até denigrem a imagem do próprio professor que parece não ter lhes dado educação.

Vê-se ênfase no respeito para com a figura do mestre. Mesmo na ausência do docente, o ideal é continuar a portar-se bem. São destacadas as atitudes negativas dos dois colegas, embora não nomeados. Importa não causar má impressão a uma pessoa desconhecida, sobretudo porque pode ser alguém com posição de destaque. Quem se comporta mal, acaba fazendo coisas ruins, como despejar a tinta e arruinar um livro. Por fım, são ratificadas as punições devidas a cada um dos estudantes rebeldes. Afınal, ser não educado, não civilizado, é conduta indesejada. A forma e o conteúdo da redação apresentam relativa complexidade, conjugando vários verbos utilizados nos tempos adequados e com correção. Para além da objetividade do discurso, está impressa uma marca de julgamento, de juízo de valor em construção sobre o que é bom e o que é mau, sobre as condutas desejadas e aquelas desprezíveis.

Os temas podem ser vinculados a saberes diversificados que à escola cabe transmitir. Voltado aos temas com elementos do ambiente natural, temos o desenvolvimento inspirado pelo título Os ovos. Essa narrativa ocupa duas páginas e meia. Há vários detalhes sobre os ovos, que abordam aspectos como a criação de galinhas, as características nutritivas, como podem ser preparados, alimentos que levam ovos no feitio, os benefícios que podem trazer à saúde. Curiosamente, a frase de encerramento da redação do menino faz uma relação entre os ovos de galinha e a Páscoa, momento em que seriam celebrados: "A festa dos ovos acontece no dia de Páscoa.” De fato, a tradição é fazer uma competição com os ovos cozidos, depois da missa de Páscoa: aquele que consegue acertar a moeda em um ovo que fica encostado em uma parede tem direito a este. É uma festa entusiasmada. Inclusive os imigrantes italianos trouxeram esta tradição para as suas colônias em território brasileiro. 
Voltado para o tratamento das relações familiares é o tema $A$ minha mãe. Na sua leitura se percebe o enaltecimento dos valores de união e vinculação familiar, assim como a representação materna orientada pelo papel social da mulher vigente à época. Por meio da análise de conteúdo detecto adjetivos e substantivos que também têm frequência em outros temas desenvolvidos. Assim inicia: "Minha mãe se chama Bortola Tancon. Ela tem 42 anos e meio. E se veste de modo simples porque é uma camponesa. É alta e magra e tem os cabelos pretos". Como esperado neste estágio de domínio da escrita, a criança será mais descritiva do que analítica, atendo-se à aparência física: "Ela usa um lenço (nos cabelos). É saudável, mas de vez em quando fica doente”. Mas eis que emergem aspectos de personalidade: "Ela é boa, mas perde a paciência quando fazemos com que a perca". Peculiar é a frase que vem a seguir e remete ao contexto social de pós I Grande Guerra Mundial: "Não é viúva e casou uma vez apenas". Para interpretá-la, cabe recordar o grande número de mulheres viúvas devido à perda dos maridos em combate. É também uma construção importante, porque faz menção à condição feminina no panorama histórico das relações sociais: neste caso, tendo como núcleo o matrimônio. Quanto a isso, podemos inferir algo sobre o fato de que, segundo o catolicismo, os casamentos devem ser únicos e durar "até que a morte os separe". Há tanto uma faceta da cultura em geral como da específica cultura religiosa. E realça que naquele contexto eram comuns atividades femininas tanto dentro como fora do lar: "Ela faz os serviços de casa assim como aqueles do campo". Aqui a dupla jornada, a valorização do trabalho como componente da vida.

Evidencia, ainda, os vínculos familiares: "Seu pai é ainda vivo e se chama Giovanni. É viva também sua mãe e se chama Madalena Zus"; “Tem dois irmãos e uma irmã”. Com essas palavras, Albino sublinha a importância dos laços familiares e de parentela. Chama a atenção para o saber escolar da mãe, valorizando-o, uma vez que mesmo se tratando de uma simples dona de casa e camponesa, ela escreve e calcula: "Sabe escrever e também fazer contas."

As referências aos relacionamentos familiares são constantes. Temos, nesta direção, um tema que solicita escrever uma carta ao avô que estaria de aniversário, cumprimentando-o. 0 tom é formal, sendo empregado o pronome de tratamento vós. Destacam-se as referências a Deus; nesta parte, se compreende que "ter um bom aniversário" depende da divindade suprema, que é quem pode garantir ainda mais anos de vida saudável. Há referências a Deus como responsável por dar bem-estar e bênçãos ou doenças e achaques. Também é notória a questão de colocar a si próprio e a família à disposição do avô para eventuais necessidades.

Encontro a sugestão de um tema em que o menino deverá desculpar-se com sua mãe: "Escrevam uma carta para a mamãe pedindo-lhe perdão por uma involuntária falta cometida”. Estimo, a partir disto, que se pudessem explorar aspectos da moralidade envolvidos, relacionados às práticas cristãs. Mas vejamos como Albino encaminha a sua redação. 0 argumento inicial diz que a mãe mandou o filho a Cencenighe para comprar remédios. E o menino, querendo fazer isso o mais rápido possível, pegou a slitta ${ }^{9}$ pequena,

\footnotetext{
9- A slitta, que lembra um trenó, não é somente um brinquedo, mas durante o inverno rigoroso era um dos únicos meios de locomoção sobre a neve. Consiste num veículo com sarrafos, leve, que se locomove sobre o gelo ou sobre a neve, geralmente com um ou dois lugares, com placa de aço debaixo, para deslizar com velocidade. 0 piloto, sentado, dirige deslocando o peso do corpo e freia com os pés.
} 
mas enquanto deslizava com ela sobre a neve perdeu duas das doze liras que lhe foram confiadas. Aí comenta sobre o estratagema que utilizou: como os pais não sabiam quanto custavam os remédios, quando chegou em casa deu como troco à mãe cinco liras e disse que os remédios custavam sete liras, quando, na verdade, custavam cinco. Eis aí a falta. E ele não teria tido coragem de falar à mãe e optou por ficar calado. Afirma que isto lhe feriu a consciência, que desde aquele dia não era mais tranquila como antes. Então, pensou muito e decidiu confessar a verdade. Evoca ainda um provérbio oriundo da ética cristão que o teria motivado: "O pecado confessado é meio perdoado". Finaliza dizendo esperar o perdão, como em outras vezes, já que a mãe é muito bondosa! E pondera que quando tiver duas liras, as restituirá.

Apelos a questões valorativas do comportamento infantil, notadamente quanto aos modos de portar-se na escola, são evidenciados em um outro tema: "Escrevam uma carta de improviso a um companheiro que vocês ouviram no pátio da escola a dizer blasfêmias e outras palavras feias". Nesse texto, Albino detém-se por três páginas inteiras. E de sua análise acrescento palavras-chave para a categorização inicial. São aspectos que chamam atenção: o fato de o menino dizer que se "arrepiou" ao ouvir as blasfêmias que o colega pronunciara. Depois, as advertências de que o professor poderia punir o colega de várias formas, não o admitindo para os exames e inclusive "batendo" na criança, que certamente choraria. Mais adiante, alerta que não cabe blasfemar diante dos demais "pequenos", que podem com isso aprender algo que não é apropriado. E conforme a um teor de religiosidade vigorosa, faz referências a Deus, que é ofendido: "Depois ofende Deus, aquele Deus que nos criou, e que foi morto por todo o mundo e então também por ti para salvar-te?”.

Segue reafirmando o argumento de que foi descabido blasfemar diante dos pequenos. Invoca as palavras do texto bíblico em que as mulheres levavam para receber bênçãos suas crianças, seres puros e virgens:

Quem dá escândalo, isto é o mau exemplo a estas almas inocentes que são puras e virgens como os lírios dos campos, faria melhor ao tomar uma pedra de moinho e jogar-se no fundo do mar ou atando-se a uma corda com um laço, prendê-la numa árvore e enforcar-se.

Os parâmetros de julgamento são fortes e a blasfêmia seria um pecado gravíssimo, a ser punido de modo violento, como o próprio suicídio. Albino comenta que o colega havia feito um "grande mal" e espera que ele "não blasfeme mais". Note-se que apesar da pouca idade do menino, ele já apresenta valores bem sedimentados, que o autorizariam a aconselhar um colega de mesma idade a não seguir maus caminhos. Emanam convicção e fortaleza de princípios, já delineados nesse estágio da sua formação. 0 zelo com a formação infantil será uma característica da futura atuação como religioso. Conta-se que Monsenhor Luciani, durante a homilia, costumava chamar para conversar com ele alguma criança presente na igreja. Ou seja, os pequenos eram seus preferidos. Esse estilo acompanhou-o até os últimos dias. Chama muito a atenção, na página em que se desenvolve esta narrativa, o sobrenome de Albino escrito na margem esquerda, em cursivas de tamanho grande na vertical e, ao pé da página, a palavra DIO (Deus) em letras maiúsculas. 
Após a análise dos vários temas presentes, indico como categorias intermediárias que emergiram: valores, comportamento infantil, família, escolarização e religiosidade. A composição da categoria valores inclui a frequência dos termos e frases que aludiram à responsabilidade, fidelidade aos companheiros e gratidão, tratados como categoriais iniciais.

\section{Dos exercícios}

Constam 12 exercícios no caderno. 0 primeiro deles aparece na segunda página. A solicitação é a de que se passem as frases para o feminino, adequando sujeitos, substantivos e adjetivos. Como vários dos exercícios seguintes, um de seus objetivos é o aprendizado do idioma com suas regras gramaticais.

Já o exercício posterior é iniciado com uma listagem de palavras, que poderiam ter sido ditadas. Em seguida, pede-se para colocar o artigo determinativo diante do termo, uma das questões características da língua italiana, que pela variedade de emprego dos artigos é complexa de ser aprendida, devendo seguir regras gramaticais e tendo-se em mente o gênero e número do substantivo, assim como as iniciais de sua escrita.

Na sequência temos uma solicitação de preenchimento ao final da linha escrita, onde havia uma lacuna que servia para os alunos escreverem o termo que se referia ao topônimo. Constam 21 frases, uma em cada linha: "Os habitantes de Canale se chamam Canalins."; "Os habitantes da Toscana se chamam toscanos”. Depois o exercício apresenta uma alteração, solicitando a correlação inversa entre o local geográfico e a designação dada a quem ali habita: "Os milaneses habitam a cidade de Milão".

Nota-se em algumas construções frasais a ausência de uma ou mais palavras, bem como sobreposições de escrita com finalidade de correção, ao que parece feitas pelo próprio estudante. Evidenciam o uso do exercício para a aprendizagem e sua fixação. Existe um número considerável de erros, o que parece não implicar correção docente, seja porque não identifico algum outro tipo de caligrafia, ou porque não aparece uso de caneta de cor assinalando algo em desacordo com a ortografia.

Em um outro momento Albino foi requisitado para acrescentar adjetivação. Se pensarmos que os adjetivos são exatamente aquilo que qualifica o ser, podem dar uma mostra de imaginários e representações presentes e que logo vieram à cabeça da criança no ato de responder. Ou seja, possivelmente admitiram-se respostas individualizadas. Seleciono algumas das 21 frases, cada uma delas ocupando uma linha. Destaco uma que foca no indivíduo: "Um escolar pode ser... negligente, vivaz". Faz pensar na relação com esta última qualidade: seria ela própria do menino Albino? Vivaz, enérgico, cheio de vida?

Diferente dos demais, é um exercício que pede para converter em prosa a poesia intitulada Aos pais. 0 texto enfatiza o papel formativo dos pais, que são aqueles que cuidam da criança, quer ela chore ou ria. Mais do que isso, eles ensinam a criança a rezar, as orações "que me fizeram conhecer aquele santo nome de Deus que existe no céu que por vós é puro e sem véu”. Fica evidente o teor devocional da formação em andamento. A ênfase está no conteúdo que permite alinhamento à categorização de relações familiares: "Os pais foram os primeiros a ensinar a dizer a verdade, ensinaram a fazer sempre as coisas boas e fugir daquelas más, e por isso o coração do filho é consagrado aos pais”. 
Diante da leitura do teor dos exercícios e considerando a frequência de termos e frases, indico como categorias intermediárias resultantes da análise de conteúdo aquelas classificadas em dois grupos: um primeiro se refere à finalidade formativa dos exercícios, cujas categorias nucleares são a ortografia e a gramática; outro é composto pela natureza das mensagens presentes na escrita nos exercícios, de onde emergem valores morais - esta indicada principalmente pela variedade de adjetivação que compôs as categoriais iniciais família e religiosidade.

\section{Na escrita escolar, um caminho a seguir: inferências e interpretações sobre a formação}

A análise de conteúdo principiou na codificação com centralidade nos ditados, temas e exercícios. Dos ditados foram geradas as categorias intermediárias valores morais, escolarização e comportamento. Depois, com base na análise de temas emergiram as categorias intermediárias valores, comportamento infantil, família, escolarização e religiosidade. Por sua vez, com base nos registros categoriais dos exercícios resultaram ortografia, gramática, valores morais, família e religiosidade. Portanto, de cada uma das unidades de registro emergiu a categorização que possibilita agora, na terceira fase do processo, elaborar inferências e interpretações.

Feito esse registro da categorização estabelecida no processo de passagem de dados brutos para dados organizados, tornou-se viável realizar um novo e último agrupamento. Para isso pautei-me pelas indicações de Bardin (1977), segundo as quais devido à homogeneidade entre as categorias iniciais e intermediárias e à sua fertilidade para as inferências, é possível o estabelecimento da categorização final com objetividade, ou seja, embasado por clareza e compreensibilidade. Assim, considerando o cotejamento entre as categorias efetuado nas duas primeiras fases da análise de conteúdo, obtive como resultado cinco categorias finais: valores morais, escolarização, comportamento, família e religiosidade. ${ }^{10}$

Visando a nutrir a interpretação, apresento aspectos do contexto histórico em que o caderno foi elaborado. Cabe lembrar que em outubro de 1922, o fascismo ascendeu ao poder na Itália e que Mussolini escolheu para o Ministério da Instrução Pública o filósofo Gentile:

[...] que consegue obter a colaboração de vários de seus discípulos, com apoio dos quais realiza, entre 1922 e 1923, ampla reforma do sistema educacional italiano, tanto sob o ponto de vista administrativo como sob o ponto de vista didático-pedagógico. (HORTA, 2008, p. 185-186).

Uma vez que o caderno se refere à vivência do menino Albino na escola elementar, trago, para efeito de contextualização, alguns dados da Reforma do Ensino Primário, à época. Pondera Horta (2008, p. 196-198) que ela foi idealizada, em 1923, pelo Diretor Geral da Instrução Primária e Popular Lombardo-Radice, podendo ser relacionada à

10- Conforme a prescrição metodológica de Bardin (1977), o critério de homogeneidade e pertinência da mensagem transmitida, ou seja, a não distorção, autoriza a fusão da categoria intermediária ortografia e gramática à categoria escolarização. 
concepção de escola primária do ministro Gentile, que a equivalia a um nível inferior para o desenvolvimento de um saber popular, o qual não chegaria a constituir uma cultura, já que esta seria destinada às elites. Esse estágio, dito elementar, dividia-se em grau preparatório ou ensino maternal com duração de três anos, grau inferior com outros três anos e grau superior, com mais dois anos; todavia, alerta-se para o fato de que em pequenas comunidades rurais italianas era comum haver apenas a oferta dos três anos iniciais, sob a supervisão de apenas um único professor, que atendia a alunos de idades entre os seis e catorze anos.

Ainda segundo a análise de Horta (2008, p.199-200), por meio de uma legislação de novembro de 1923 que estipulou horários, programa e orientações didáticas para a escola elementar, Lombardo-Radice acrescentou aos princípios filosóficos de Gentile métodos e conteúdos progressistas, os quais deveriam envolver professores e alunos. Entretanto, previam liberdade metodológica para os mestres, desde que orientada para as finalidades que o Estado esperava do trabalho docente. Isso foi expresso em uma Ordinanza Ministeriale, de textualidade impregnada de adjetivações e valores:

Só aquele que busca a companhia dos mais humildes e dos pequenos, tendo antes gozado da companhia espiritual dos melhores espiritos humanos, sente não estar rebaixando-se, e é capaz de falar com espirito religioso, qualquer que seja o objeto do seu ensinamento e a idade dos seus discípulos. (HORTA, 2008, p. 200, grifos meus).

Deste modo, colocava-se em evidência a centralidade no plano cultural, indicada pela religiosidade como categoria de análise. De modo consonante, em diversas partes do conteúdo do caderno reverberam referências a valores próprios do catolicismo e a Deus. E uma vez que um dos objetivos do estudo tem como norte discutir a existência de nexos entre os conteúdos do caderno e a vida posterior do aluno a quem pertenceu, sublinho a inspiração nos fundamentos cristãos manifesta em escritas de ditados, temas e exercícios. Particularmente, esse elo foi destacado pelo próprio Albino Luciani quando escreveu memórias de sua infância e se reportou a eventos vividos em Canale d'Agordo, como o impacto emocional da música do órgão da igreja local.

Outrossim, afloraram nas composições registradas no caderno de Albino as influências formativas da família e da escolarização em harmonia com princípios de comportamento. A natureza das práticas educativas apresentadas nos ditados, nos temas e nos exercícios é desvelada pela terminologia empregada, cuja frequência permitiu identificar nas relações familiares e escolares o atendimento de preceitos ético-morais e também de atitudes cristãs, enfatizando a caridade, a compaixão, o respeito e o amor à família; alguns textos falam da disciplina, dos castigos e de faltas como jogar pedras, mentir, ser hipócrita e blasfemar contra Deus.

Se conduzido pelas linhas do caderno de Albino perscruto em sua escrita escolar, acrescento, para fins da composição analítica pretendida, que o menino se tornou um apaixonado pela leitura. A princípio foi orientado para escritas e leituras de base religiosa, mas não se esquivou de outros textos. Sua biblioteca, preservada no museu que leva seu nome, possui o que denominava de uma coleção discreta de romances, incluindo autores 
como Verne, Salgari e Mioni, além de livros de viagens e de aventuras, como Le Vie d'Italia e del mondo. Quando orientador de seminaristas, não se furtou a solicitar obras como a Enciclopedia dei ragazzi, recomendando que sua leitura fosse feita metade como estudo, metade com vagar. Ao lado dessa literatura, formou um acervo de revistas de série como La rivista dei giovani, La rivista del clero italiano e Pro Familia, que figuravam ao lado de Le Missioni dela Compagnia di Gesù.

Segundo Horta (2008, p. 200), essa ênfase em aspectos religiosos do catolicismo e nas suas tradições, entranhada na cultura escolar italiana, tinha justificativas:

A referência ao espírito religioso não é casual. A Reforma Gentile colocava "o ensino da doutrina cristã na forma transmitida pela tradição católica" como "fundamento e coroamento da instrução elementar em todos os seus graus". Concretizando tal dispositivo, o Programa de 1923 reservava uma a duas horas semanais do horário escolar para o ensino da religião. Além do ensino religioso, o Programa elaborado por Lombardo-Radice, fiel à concepção pedagógica que o havia inspirado, introduz no ensino primário o desenho, o canto e os trabalhos manuais, além das ocupações recreativas.

Logo, posso afirmar que a categoria valores também é central, sendo composta de uma infinidade de palavras-chave agrupadas devido à proximidade quanto ao conteúdo semântico. 0 teor da escrita presente no caderno de Albino Luciani sublinha um papel de produção e transmissão de valores vinculados a vários fundamentos associados à formação, amalgamando hábitos e atitudes que são pautados pela escola e estão em consonância com a moralidade que orientava não somente a vida familiar, mas o comportamento nos planos culturais, sociais e políticos mais amplos.

Embora salientando um momento pautado pelo teor de um caderno, a análise não ignora o papel de outros fatores formativos na vida. Acrescento uma ponderação do então Cardeal Luciani, em uma entrevista em que fala da influência na sua juventude do seu "pai espiritual" Dom Fillipo Carli, arcipreste e vigário de Canale d'Agordo de 1919 a 1934. Segundo comenta, deste aprendeu como estabelecer a obra pastoral, a relação com a gente, o estilo jornalístico simples de escrever. Afirmou: "Quanto ao pároco, me seja permitido reevocar aqui a figura do meu... Quanto era bom e circunspecto mais no encorajar do que no reprovar... Quanto lhe devo!" (LUCIANI, 1977, p. 256).

Em boa medida, a análise de conteúdo permitiu conhecer o que se ensinou e como foi ensinado em um processo de escolarização, em dado momento histórico. Resultaram interpretações que vinculam aspectos culturais - que foram apresentados e deviam ser aprendidos na infância - ao posterior percurso de formação que conduziu à escolha profissional de essência religiosa. A frequência de termos do campo religioso sinaliza fortemente a transmissão de valores estimuladores da vocação profissional: os elementos formativos inoculados na escrita podem ser entendidos como basilares da formação infantil, gerando efeitos preservados e influentes na futura conduta e atuação.

Mesmo sublinhando o caderno como um instrumento de aculturação, anunciando disposições do sujeito e saberes que ecoaram na formação de Albino Luciani, adiciono alguns outros aspectos de sua trajetória de vida, centrados também na escolarização, que se somam e combinam para que as ilações propostas nos objetivos deste estudo 
sejam configuradas. Tendo-se em mente as categorias valores morais, escolarização, comportamento, família e religiosidade, podemos estimar a sua presença formativa, já algo sedimentada, quando do ingresso de Albino no Seminário Menor de Feltre. Em 17 de outubro de 1923, ao completar onze anos e após ter concluído a quarta elementar, o menino adentrou na carreira de formação religiosa, ficando na instituição até 1928, cursando os cinco anos de ginásio. Assim, a adolescência foi vivida nesse ambiente. Em carta de outubro de 1962, escreveu o Bispo Luciani ${ }^{11}$ : "O Seminário foi minha casa, a minha família, a isso, depois que ao Senhor e aos meus pais, devo tudo."

Aquelas disposições que foram semeadas na escola elementar e detectadas no conteúdo do caderno, entendo terem sido reforçadas enquanto Albino foi seminarista. Passando ao Seminário Maior de Belluno, lá permaneceu entre 1928 e 1958, ou seja, por trinta anos, sete dos quais como estudante e outros vinte e três como professor. Quer dizer, antes de tornar-se bispo, passou trinta e cinco de seus quarenta e seis anos em ambientes de formação e práticas religiosas, completando ali seus estudos de teologia.

Portanto, o lugar de destaque que o caderno do Papa João Paulo I ocupa no acervo museológico evidencia um valioso registro, ao mesmo tempo produto e produtor de uma cultura escolar alicerçada em valores, comportamentos e saberes historicamente transmitidos. Tal como um relicário, o caderno de Albino Luciani preserva um conteúdo de grande valor, desvelando modos de formação encravados na escrita escolar.

\section{Referências}

BARDIN, Laurence. Análise de conteúdo. Lisboa: Edições 70, 1977.

GVIRTZ, Silvina; LARRONDO, Marina. Os cadernos de classe como fonte primária de pesquisa: alcances e limites teóricos e metodológicos para sua abordagem. In: MIGNOT, Ana Chrystina Venancio (Org.). Cadernos à vista: escola, memória e cultura escrita. Rio de Janeiro: EdUERJ, 2008. p. 35-48.

HORTA, José Silvério Baia. A educação na Itália fascista: as Reformas Gentile (1922-1923). História da Educação, Pelotas, v. 12, n. 24, p. 179-223, jan./abr. 2008.

LUCIANI, Albino. Lettera per la Giornata del Seminario. 27 de outubro de 1962.

LUCIANI, Albino. Quaderno di Luciani Albino no. 8: classe IVa. Elementare. Forno di Canale: [s. n], 1922-23.

LUCIANI, Albino. Entrevista. Rivista Diocesana del Patriarcato di Venezia, Venezia, Giugno, 1977.

SERAFINI, Loris. L'organo di Gaetano Callido e la tradizione musicale nell'antica Pieve di Canale d'Agordo. Canale d'Agordo: Tipografia Piave. 2004.

11- Em 27 de dezembro de 1958 foi consagrado Bispo de Vittorio Veneto, pelas mãos do papa João XXIII. 
VIÑAO, Antonio. Os cadernos escolares como fonte histórica: aspectos metodológicos e historiográficos. In: MIGNOT, Ana Chrystina Venancio (Org.). Cadernos à vista: escola, memória e cultura escrita. Rio de Janeiro: EdUERJ, 2008, p. 15-33.

Recebido em: 04.11.2017

Revisões em: 18.05.2018

Aprovado em: 13.06.2018

Ademir Valdir dos Santos é pesquisador do Departamento de Estudos Especializados em Educação, da Universidade Federal de Santa Catarina (UFSC). É líder do Grupo de Estudos e Pesquisas em História da Educação e Instituições Escolares de Santa Catarina. 